\title{
A double-edged sword: how oncogenes and tumor suppressor genes can contribute to chromosomal instability
}

\author{
Bernardo Orr ${ }^{1,2}$ and Duane A. Compton ${ }^{1,2}$ * \\ 1 Department of Biochemistry, Geisel School of Medicine at Dartmouth, Hanover, NH, USA \\ 2 The Norris-Cotton Cancer Center, Geisel School of Medicine at Dartmouth, Hanover, NH, USA
}

Edited by:

Samuel F. Bakhoum, Geisel School of

Medicine at Dartmouth, USA

Reviewed by:

Valerio Donato, New York University

Medical Center, USA

Holger Bastians, University Medical

Center Goettingen, Germany

\section{*Correspondence:}

Duane A. Compton, Department of

Biochemistry, Geisel School of

Medicine at Dartmouth, HB7200,

Hanover, NH 03755, USA

e-mail: duane.a.compton@

dartmouth.edu
Most solid tumors are characterized by abnormal chromosome numbers (aneuploidy) and karyotypic profiling has shown that the majority of these tumors are heterogeneous and chromosomally unstable. Chromosomal instability $(\mathrm{CIN})$ is defined as persistent missegregation of whole chromosomes and is caused by defects during mitosis. Large-scale genome sequencing has failed to reveal frequent mutations of genes encoding proteins involved in mitosis. On the contrary, sequencing has revealed that most mutated genes in cancer fall into a limited number of core oncogenic signaling pathways that regulate the cell cycle, cell growth, and apoptosis. This led to the notion that the induction of oncogenic signaling is a separate event from the loss of mitotic fidelity, but a growing body of evidence suggests that oncogenic signaling can deregulate cell cycle progression, growth, and differentiation as well as cause $\mathrm{CIN}$. These new results indicate that the induction of $\mathrm{CIN}$ can no longer be considered separately from the cancer-associated driver mutations. Here we review the primary causes of $\mathrm{CIN}$ in mitosis and discuss how the oncogenic activation of key signal transduction pathways contributes to the induction of CIN.

Keywords: aneuploidy, chromosomal instability, CIN, oncogenic signaling, mitosis, chromosome segregation, cancer, genomic instability

\section{ANEUPLOIDY AND CIN IN TUMORS}

Most solid tumors have abnormal chromosome numbers (aneuploidy) and large-scale structural genomic rearrangements (Hanahan and Weinberg, 2000, 2011). Karyotypic analyses show that tumors display both intra- and inter-tumor heterogeneity suggesting that most tumors are not only aneuploid, but also chromosomally unstable. Chromosomal instability (CIN) is defined as a persistent high rate of gain/loss of whole chromosomes (Lengauer et al., 1997). CIN is present in most aneuploid solid tumors and is an important hallmark of genome instability associated with cancer. Since CIN (and the consequent aneuploidy) is caused by aberrant chromosome segregation, it is probable that most cancer cells acquire defects in the machinery responsible for faithful chromosome segregation in mitosis. These defects could arise through either mutation of genes encoding essential mitotic proteins or by imbalances in protein levels or activities that reduce mitotic fidelity (reviewed in Schvartzman et al., 2010; Nicholson and Cimini, 2011).

Aneuploidy and CIN commonly go hand-in-hand because the proximal outcome of CIN is to create deviations in the karyotype. However, it is important to note that aneuploidy and CIN are distinct (Thompson and Compton, 2008). Aneuploidy is a state of abnormal chromosome number and some tumors have abnormal, yet stable karyotypes (i.e., all the cells in the tumor have the same defective karyotype). CIN is a high rate of chromosome mis-segregation that enhances karyotypic diversity in cells within the same tumor, a feature commonly associated to tumor aggressiveness (Storchova and Pellman, 2004; Geigl et al., 2008). On average, CIN cancer cells mis-segregate a chromosome once in every one to five cell divisions (Lengauer et al., 1997; Thompson and Compton, 2008), an event which is thought to drive the genomic re-shuffling that allows cells to acquire new phenotypes such as drug resistance. Significantly, both aneuploidy and CIN have been associated with poor patient prognosis, metastasis, and resistance to chemotherapeutics (Kuukasjarvi et al., 1997; Carter et al., 2006; Walther et al., 2008; Swanton et al., 2009; Bakhoum et al., 2011; Lee et al., 2011; Smid et al., 2011; McGranahan et al., 2012) and recent reports have shown that aneuploidy and CIN play a causal role in tumorigenesis and relapse (Weaver et al., 2007; Baker et al., 2009; Sotillo et al., 2010). Thus, understanding the mechanisms that cause CIN offers an attractive possibility to intervene in tumor aggressiveness and enhance the efficiency of cancer therapy.

Large-scale genome sequencing has revealed the most commonly mutated genes in cancer (Cancer Genome Atlas Research Network, 2008, 2011, 2012; Jones et al., 2008). These cancercausing genes encode proteins responsible for cell cycle control and cell signaling pathways responsible for cell growth and death. Genome sequencing analyses have revealed very few mutations in genes that encode proteins involved in chromosome segregation during mitosis. Thus, the persistent mis-segregation of chromosomes in CIN tumor cells has been largely attributed to errors arising during mitosis that were not directly linked to the driver mutations in oncogenic signaling pathways. However, the idea that 
CIN is caused by events that are independent of the oncogenic signaling pathways is beginning to falter. Emerging data show that $\mathrm{CIN}$ and the oncogenic signaling pathways responsible for driving tumor formation are closely interrelated. Here we provide a brief overview of the mitotic defects that commonly cause CIN and then explain how oncogenic signaling pathways that are commonly de-regulated in cancer influence mitosis to induce CIN.

\section{CAUSES OF CIN IN CANCER CELLS}

The persistently high rate of chromosome mis-segregation associated with CIN in tumor cells has been attributed to four primary defects in mitosis (Figure 1, inner circle). The first mitotic defect proposed to cause CIN was an impaired spindle assembly checkpoint (SAC). This idea stemmed from a study demonstrating that CIN is caused by mutational inactivation of the essential SAC component Bub1 (Cahill et al., 1998). Although the initial identification of mutations in Bub1 was encouraging, subsequent genome sequencing showed that mutational inactivation of SAC components is quite rare (Barber et al., 2008). Moreover, complete loss of SAC function is lethal (reviewed in Kops et al., 2004; Kops et al., 2005). Also, follow up experiments demonstrated that most aneuploid cancer cells possess a functional SAC (Tighe et al., 2001; Gascoigne and Taylor, 2008). These results gave rise to the alternative hypothesis that partial loss of SAC function is responsible for causing CIN. Evidence in favor of this view is derived from the high incidence of aneuploidy and tumorigenesis in mice engineered to have weakened SAC activity (Michel et al., 2001; Dai et al., 2004). Moreover, in humans, reduced SAC activity has been observed in individuals with Mosaic Variegated Aneuploidy (MVA), an extremely rare disease strongly linked to mutations in SAC component BubR1 (Hanks et al., 2004; Suijkerbuijk et al., 2010).

The second mitotic defect shown to cause CIN is the persistence of errors in kinetochore-microtubule (k-MT) attachments

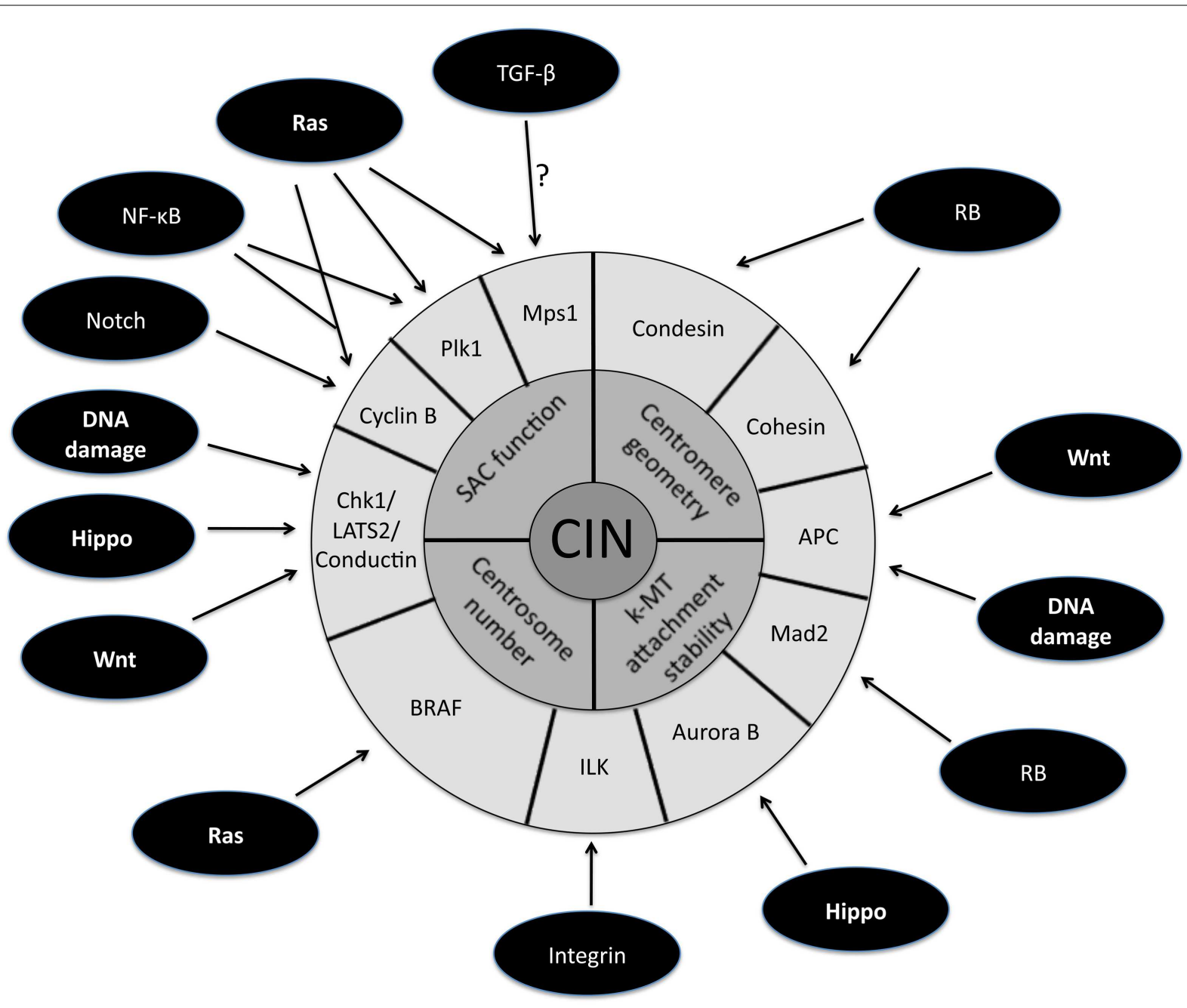

FIGURE 1 | Schematic representation of the downstream targets of oncogenic signaling pathways that affect mitotic fidelity. The inner circle represents chromosomal instability $(\mathrm{CIN})$ and the middle circle is composed of the four primary defects in mitosis known to cause CIN. The downstream targets of oncogenic pathways involved in the four primary CIN-causing mitotic defects comprise the outer circle. Note that some downstream targets (e.g., APC) have been demonstrated to play a role in more than one $\mathrm{CIN}$-causing mitotic defect. 
as revealed by live imaging of cancer cells (Thompson and Compton, 2008; Compton, 2011). Faithful chromosome segregation relies on the bi-oriented attachment of chromosomes to spindle microtubules. Kinetochores in human cells bind approximately 25 microtubules and errors in the orientation of k-MT attachments arise through the stochastic nature of interactions between microtubules and kinetochores. Merotely is a specific k-MT attachment error defined by single kinetochores that simultaneously attach microtubules oriented toward both spindle poles. Merotely avoids detection by the SAC since kinetochores attain full occupancy of microtubules (albeit with improper orientation). Thus, if cells enter anaphase with merotelically attached kinetochores, the chromatid attached to both spindle poles will fail to segregate properly and lag near the central spindle as other chromosomes move poleward. This can cause chromosome mis-segregation and lagging chromosomes in anaphase were the most common defect in mitosis observed by live cell imaging in cancer cell lines. Error-free mitosis is promoted by microtubule detachment from kinetochores and the stability of k-MT attachments is regulated through the concerted action of several mitotic kinases, notably Aurora B (Lampson et al., 2004; Pinsky et al., 2006). Direct measurements show that many CIN cancer cells have hyperstable k-MT attachments which undermines their ability to correct errors and leads to high rates of chromosome mis-segregation. Importantly, increasing the detachment rate of k-MT improves error correction and is sufficient to restore faithful chromosome segregation in CIN cancer cells (Bakhoum et al., 2009a,b; Kabeche and Compton, 2012). These results are the first genetic demonstration of the correction of CIN and provide direct causal evidence that impaired regulation of k-MT attachments is an underlying cause of CIN in human cancer cells.

The third mitotic defect leading to $\mathrm{CIN}$ is the presence of supernumerary centrosomes. Centrosome duplication is tightly regulated during the cell cycle such that normal cells enter mitosis with only two. Two centrosomes foster bipolar spindle formation, yet it has been well documented that cancer cells frequently enter mitosis with more than two centrosomes leading to multipolar spindles (reviewed in Nigg, 2002; Fukasawa, 2005; Bakhoum and Compton, 2009; Anderhub et al., 2012; Vitre and Cleveland, 2012). Interestingly, the frequency of multipolar spindles is higher in prometaphase than in anaphase indicating that centrosomes cluster to promote bipolar spindle formation prior to anaphase onset (Brinkley, 2001; Quintyne et al., 2005; Basto et al., 2008). Despite these centrosome clustering mechanisms, the presence of extra centrosomes prolongs mitosis by delaying satisfaction of the SAC even in cells with bipolar spindles (Yang et al., 2008) suggesting that not all kinetochores are properly attached to microtubules. In support of this, recent studies have shown that the transient multipolar spindles caused by supernumerary centrosomes increase the propensity of merotelic k-MT attachments and elevate the frequency of chromosome mis-segregation (Ganem et al., 2009; Silkworth et al., 2009). Thus, extra centrosomes increase the rate of formation of k-MT attachment errors leading to CIN.

The fourth mitotic defect causing CIN is tied to centromere geometry. The integrity of centromeric structure ensures that kinetochores are positioned in a back-to-back configuration. This creates a geometric constraint that increases the probability that sister kinetochores of a single chromosome will achieve proper bi-orientated attachments to spindle microtubules (Indjeian and Murray, 2007; Loncarek et al., 2007; Sakuno et al., 2009). It has been shown that defects in pericentromeric cohesion undermine the establishment of proper k-MT attachments (Ng et al., 2009). The consequence is an increased rate of formation of k-MT attachment defects that leads to elevated rates of chromosome mis-segregation.

\section{HOW ONCOGENIC PATHWAYS INDUCE CIN}

A large fraction of tumors have driver mutations in genes encoding components of a handful of conserved oncogenic pathways. Although the specific genes that are mutated within each pathway can differ between tumors from different individuals, the common feature is that most tumors have mutations that cause aberrant signaling in these key signal transduction pathways. For example, sequencing analyses of pancreatic cancers and glioblastomas revealed that a core set of 12 signaling pathways are genetically altered in $67-100 \%$ of all tumors (Cancer Genome Atlas Research Network, 2008; Jones et al., 2008). Here we discuss how the oncogenic activation of these signaling pathways contributes to the induction of CIN (Figure 1; Table 1).

\section{THE RB PATHWAY}

The retinoblastoma tumor suppressor protein $(\mathrm{pRB})$ is a key regulator of the G1 to $S$ transition during the cell cycle (Burkhart and Sage, 2008). It was one of the first tumor suppressor genes identified and is commonly inactivated in several tumor types (Marshall, 1991). It is common for tumors with inactivating mutations in pRB to be aneuploid with an increased susceptibility to changes in DNA ploidy (Isaac et al., 2006; Mayhew et al., 2007; Srinivasan et al., 2007; Amato et al., 2009a,b), and recent reports have shown that $\mathrm{pRB}$ influences mitosis through a function that is independent of its role in cell cycle progression (Sage and Straight, 2010). The E2F transcription factor family proteins are downstream targets that are negatively regulated by $\mathrm{pRB}$. These transcription factors regulate the expression of genes whose products are involved in chromatin assembly/condensation, chromosome segregation, and in the mitotic checkpoint such that loss of pRB increases their transcription (Ren et al., 2002). For example, pRB negatively regulates the transcription of the gene encoding SAC protein Mad2 and loss of $\mathrm{pRB}$ signaling leads to overexpression of Mad2 giving rise to aneuploidy and CIN (Hernando et al., 2004). A recent study showed that Mad2 stabilizes k-MT attachment in a function that is distinct from its role in the SAC (Kabeche and Compton, 2012). Overexpression of Mad2 hyper-stabilizes k-MT attachments and increases the rate of formation of k-MT attachment errors leading to CIN.

Loss of pRB also alters chromatin structure. For example, pRB has been shown to interact with the Condensin II complex and participate in mitotic chromosome condensation. Loss of $\mathrm{pRB}$ accelerates both loss of heterozygosity in the absence of p53 and the rate of tumor formation (Coschi et al., 2010). Moreover, disruption of $\mathrm{pRB}$ in mice has been shown to disrupt pericentric heterochromatin leading to centromere fusions, chromosome missegregation, and consequently aneuploidy (Isaac et al., 2006). This effect on centromere integrity was corroborated in a subsequent 
Table 1 | Table summarizing the CIN-causing mitotic phenotypes observed in different cell types and/or models upon de-regulated oncogenic signaling.

\begin{tabular}{|c|c|c|c|c|}
\hline Pathway & Gene(s) & Mitotic phenotype & Model & Reference \\
\hline & $\mathrm{RB}$ & $\begin{array}{l}\text { Chromosome condensation; impaired } \\
\text { centromere structure; heterochromatin } \\
\text { structure; chromosome mis-segregation }\end{array}$ & $\begin{array}{l}\text { MEFs; RPE1; Drosophila } \\
\text { neuroblasts }\end{array}$ & $\begin{array}{l}\text { Isaac et al. (2006), Coschi et al. } \\
\text { (2010), Manning et al. (2010) }\end{array}$ \\
\hline & $\begin{array}{l}\text { RB, p107, } \\
\text { p130 }\end{array}$ & Chromatid breaks; cohesion defects & MEFs & $\begin{array}{l}\text { Manning et al. (2010), van Harn } \\
\text { et al. (2010) }\end{array}$ \\
\hline \multirow[t]{4}{*}{ Wnt } & $\begin{array}{l}\text { Conductin/AXIN2 } \\
\text { and APC }\end{array}$ & $\begin{array}{l}\text { Premature centrosome separation } \\
\text { (Plk1-dependent); Impaired SAC } \\
\text { (Plk1-dependent) }\end{array}$ & $\begin{array}{l}\text { MEFs; SW480, U2OS, HCT116, } \\
\text { DLD1, HEK293T, HeLa }\end{array}$ & $\begin{array}{l}\text { Hadjihannas et al. (2006), } \\
\text { Hadjihannas et al. (2010), Ruan et al. } \\
\text { (2012) }\end{array}$ \\
\hline & GSK3 $\beta$ & $\begin{array}{l}\text { Mis-alignment; chromosome } \\
\text { mis-segregation; micronuclei formation }\end{array}$ & $\begin{array}{l}\text { HeLa, HEK293T, Drosophila } \\
\text { embryos }\end{array}$ & $\begin{array}{l}\text { Wakefield et al. (2003), Bobinnec } \\
\text { et al. (2006), Tighe et al. (2007) }\end{array}$ \\
\hline & $\beta$-catenin & $\begin{array}{l}\text { Loss of centrosome separation; } \\
\text { monopolar spindle formation; } \\
\text { chromosome condensation }\end{array}$ & $\begin{array}{l}\text { HeLa, HEK293T, NIH-3T3, MDCK, } \\
\text { U2OS, DID1, HCT116 }\end{array}$ & $\begin{array}{l}\text { Kaplan et al. (2004), Bahmanyar } \\
\text { et al. (2008), Davalos et al. (2012) }\end{array}$ \\
\hline & APC & Hyper-stabilization of k-MT attachment & $\begin{array}{l}\text { Mouse ES cells, Ptk2, HT29, } \\
\text { SW480, Caco2, LoVo, HCT116, } \\
\text { RKO, HEK293T, HeLa, RPE1 }\end{array}$ & $\begin{array}{l}\text { Fodde et al. (2001), Zumbrunn et al. } \\
\text { (2001), Green and Kaplan (2003), } \\
\text { Green et al. (2005), Draviam et al. } \\
\text { (2006), Bakhoum et al. (2009a) }\end{array}$ \\
\hline \multirow{2}{*}{$\begin{array}{l}\text { DNA } \\
\text { damage }\end{array}$} & Chk2/BRCA1 & $\begin{array}{l}\text { Abnormal mitotic spindle assembly; } \\
\text { lagging chromosomes }\end{array}$ & HCT116, HeLa, BJ-hTERT & Stolz et al. (2010b) \\
\hline & DNA-PKcs & Abnormal spindle formation & HeLa, AT5BIVA & Shang et al. (2010) \\
\hline \multirow[t]{3}{*}{ Ras } & HRas & Weakened SAC & PCCL3 & Knauf et al. (2006) \\
\hline & KRas & Chromosome mis-segregation & DLD1, HCT116 & Luo et al. (2009) \\
\hline & BRAF & $\begin{array}{l}\text { Impaired SAC (Mps1-dependent); } \\
\text { supernumerary centrosomes }\end{array}$ & $\begin{array}{l}\text { SK-MEL-5, SK-MEL-28, A375, SBcl2, } \\
\text { hTERT-HME }\end{array}$ & Cui et al. (2010) \\
\hline Notch & Notch & Mitotic delay (CycB1-dependent) & KS-IMM, KS-Y1 & Curry et al. (2007) \\
\hline \multirow[t]{2}{*}{ TGF- $\beta$} & Ski & $\begin{array}{l}\text { Weakened SAC function; lagging } \\
\text { chromosomes/chromosome bridges; } \\
\text { micronuclei formation }\end{array}$ & $\begin{array}{l}\text { Primary MEFs, SV-40 immortalized } \\
\text { MEFs }\end{array}$ & Marcelain et al. (2012) \\
\hline & Smad2/3 & Impaired SAC function? & Sw480, HeLa & Zhu et al. (2007) \\
\hline
\end{tabular}


Table 1 | Continued

\begin{tabular}{|c|c|c|c|c|}
\hline Pathway & Gene(s) & Mitotic phenotype & Model & Reference \\
\hline$N F-\kappa B$ & IкB & $\begin{array}{l}\text { Centrosome function (Aurora } \\
\text { A-dependent); Mitotic arrest (CycB1 and } \\
\text { Plk1-dependent); chromosome } \\
\text { mis-segregation }\end{array}$ & HeLa, COS7, Primary MEFs & $\begin{array}{l}\text { Prajapati et al. (2006), Irelan et al. } \\
\text { (2007) }\end{array}$ \\
\hline Integrin & ILK & $\begin{array}{l}\text { Centrosome clustering (TACC3 and } \\
\text { ch-TOG-dependent); Hyper-stabilization of } \\
\text { k-MT dynamics }\end{array}$ & $\begin{array}{l}\text { BT549, MDA-MB-231, MCF7, } \\
\text { MCF10A, 184-hTERT, PC3, DU145, } \\
\text { BPH-1, HEK293T, HeLa, IMR-90 }\end{array}$ & $\begin{array}{l}\text { Fielding et al. (2008), Fielding et al. } \\
\text { (2011), Lim et al. (2013) }\end{array}$ \\
\hline \multirow[t]{3}{*}{ Hippo } & NDR1/Fry/MST2 & Chromosome misalignment & HeLa & Chiba et al. (2009) \\
\hline & MST1 & $\begin{array}{l}\text { Centrosome overduplication; Stabilization } \\
\text { of k-MT attachments (Aurora } \\
\text { B-dependent) }\end{array}$ & HeLa, U2OS, PT67, COS7, RPE1 & $\begin{array}{l}\text { Hergovich et al. (2009), Oh et al. } \\
\text { (2010) }\end{array}$ \\
\hline & KIBRA & $\begin{array}{l}\text { Defects in mitotic spindle formation; } \\
\text { chromosome misalignment }\end{array}$ & HEK293T, MCF7, HeLa & Zhang et al. (2012) \\
\hline
\end{tabular}

study showing that loss of pRB, p107, and p130 in mouse embryonic fibroblasts (MEFs) causes a G2 arrest coupled with DNA damage which results in chromatid breaks and cohesion defects in mitotic chromosomes (van Harn et al., 2010). Finally, Manning and co-workers demonstrated that $\mathrm{pRB}$ depletion alters the centromeric localization of CAP-D3/condensin II, leading to distorted centromere structure and increased inter-kinetochore distance. These centromere distortions increase the propensity of merotelic k-MT attachment leading to CIN (Manning et al., 2010). Taken together, these studies show that in addition to altered cell cycle regulation, the loss of $\mathrm{pRB}$ alters centromere geometry to increase the rate of formation of k-MT attachment errors and hyperstabilizes k-MTs to reduce the rate of correction of attachment errors (Hernando et al., 2004; Isaac et al., 2006; Manning et al., 2010; van Harn et al., 2010).

\section{THE WNT SIGNALING PATHWAY}

The Wnt signaling pathway plays a critical role in stem cell renewal, survival, and differentiation, as well as in the normal development and homeostasis of tissues including the mammary gland (BorasGranic and Wysolmerski, 2008). De-regulation of Wnt signaling plays a causal role in breast cancer (reviewed in Prosperi and Goss, 2010). Aberrant Wnt signaling has been shown to play role in accelerating tumorigenesis by promoting CIN in the absence of p53 (Donehower et al., 1995) and numerous studies have implied that Wnt signaling is directly involved in mitotic regulation (reviewed in Niehrs and Acebron, 2012).

Excessive Wnt signaling up-regulates expression of conductin/AXIN2, a protein involved in SAC signaling and centrosome cohesion (Hadjihannas and Behrens, 2006; Hadjihannas et al., 2010). Conductin localizes to mitotic spindles and high conductin expression attenuates SAC activity via a Pololike kinase 1 (Plk1)-dependent mechanism (Hadjihannas et al., 2006). Additionally, Axin phosphorylation by Plk1 is essential for proper centrosome function (Ruan et al., 2012). Plk1 also phosphorylates Disheveled 2 (Dvl2), a central component of the Wnt signaling pathway that plays a role in SAC activation by recruiting SAC components Mps1, Bub1, and BubR1 to kinetochores (Kikuchi et al., 2010). In addition to conductin and Dvl2, both GSK3 $\beta$ and $\beta$-catenin have been shown to be involved in centrosome separation and to regulate spindle microtubules during mitosis (Wakefield et al., 2003; Kaplan et al., 2004; Bobinnec et al., 2006; Bahmanyar et al., 2008). Consistently, treating human cells with GSK3 $\beta$-inhibitors was shown to induce CIN (Tighe et al., 2007). Wnt signaling also regulates mitosis through the conserved protein Adenomatous Polyposis Coli (APC). APC enhances the correction of k-MT attachment errors because truncation or depletion of APC in human cells increases k-MT stability through interactions with microtubule plus-ends and induces chromosome mis-segregation (Fodde et al., 2001; Zumbrunn et al., 2001; Green and Kaplan, 2003; Green et al., 2005; Draviam et al., 2006; Bakhoum et al., 2009a). However, since APC is commonly mutated and/or truncated in tumor cells, the role of APC in regulating microtubule plus-ends is most likely independent of Wnt signaling. Finally, SMC2, a core subunit of the condensin complex, is a transcriptional target of the Wnt signaling pathway demonstrating a functional link between Wnt signaling and chromosome condensation (Davalos et al., 2012). These results suggest that excessive Wnt signaling decreases the efficiency of the correction of k-MT attachment errors and increases the rate of formation of k-MT attachment errors by stabilizing k-MT attachments, influencing centrosome cohesion, and affecting centromere geometry.

\section{THE RAS SIGNALING PATHWAY}

The Ras oncogene is one of the most commonly mutated genes across an array of cancer types and de-regulated signaling through receptor-tyrosine kinase pathways caused by mutant Ras (or its GAP or GEF) affects cell cycle regulation, apoptosis, and cell 
survival (reviewed in Malumbres and Barbacid, 2003). Apart from the well-characterized roles that Ras signaling plays in cell cycle progression, it has also been implicated in the maintenance of genome integrity and this hypothesis gains strength with several important observations (reviewed in Kamata and Pritchard, 2011). First, cells harboring gain-of-function Ras mutations exhibit changes in DNA ploidy and genomic rearrangements in mouse models and rat cells (Ichikawa et al., 1990; Denko et al., 1994; Saavedra et al., 2000; Baker et al., 2013). Consistently, oncogenic HRas ${ }^{\mathrm{G} 12 \mathrm{~V}}$ expression in rat thyroid cells was shown to weaken the SAC response to microtubule targeting drugs (Knauf et al., 2006). Furthermore, expression of oncogenic Ras at endogenous levels is sufficient to generate chromosome mis-segregation in cancer cells perhaps through Plk1 and the Anaphase-Promoting Complex/Cyclosome (APC/C) (Luo et al., 2009). Importantly, an elegant set of experiments using primary MEFs grown under conditions that preserve diploid karyotypes showed that expression of $\mathrm{HRas}^{\mathrm{G} 12 \mathrm{~V}}$ resulted in the induction of CIN, an outcome that was enhanced by the absence of p53 (Woo and Poon, 2004).

The ERK pathway is the best-characterized signaling pathway downstream of Ras and its contribution to mitotic progression in human cells appears to be cell-type dependent. For example, depletion of ERK1/2 in keratinocytes, but not in fibroblasts, induces a CyclinB1-dependent G2/M arrest (Dumesic et al., 2009). Additionally, ERK1/2 has been detected at centrosomes and kinetochores during mitosis (Shapiro et al., 1998; Lou et al., 2004) but a functional role for ERKs during mitosis has so far remained elusive. Furthermore, another downstream target of Ras is Raf kinase, and human melanoma cells expressing oncogenic B-RAF ${ }^{\mathrm{V} 600 \mathrm{E}}$ were shown to "hyperactivate" the SAC through stabilization of Mps1 and induce supernumerary centrosomes resulting in chromosome mis-segregation accompanied by aneuploidy (Cui et al., 2010). These reports provide evidence that deranged Ras signaling can induce CIN although the precise molecular mechanism leading to elevated chromosome mis-segregation remain elusive.

\section{THE TRANSFORMING GROWTH FACTOR BETA (TGF- $\beta$ ) SIGNALING PATHWAY}

TGF- $\beta$ signaling is involved in the regulation of cell proliferation, differentiation, motility, adhesion, and apoptosis and therefore de-regulation of the TGF- $\beta$ pathway is thought to play a critical function in cancer development. However, the role of TGF- $\beta$ signaling in tumorigenesis is somewhat paradoxical since it acts as a tumor suppressor at early stages of cancer development and as an oncogene at terminal stages of the disease by initiating a transcriptional program required for the activation of genes involved in cell metastasis and invasion (reviewed in Massague, 2008; BarcellosHoff and Akhurst, 2009; Padua and Massague, 2009). The primary intracellular mediators of TGF- $\beta$ are the Smad proteins, which are phosphorylated and activated by the TGF- $\beta$ Receptor I (T $\beta$ RI) kinase. This phosphorylation event promotes translocation of Smad proteins to the nucleus where they cooperate with transcription factors to regulate gene expression (Derynck and Zhang, 2003).

The link between TGF- $\beta$ signaling and mitosis came from the observation that endogenous Smads bind microtubules and that microtubule-depolymerization in cells triggers phosphorylation of Smad2 (Dong et al., 2000). Subsequently, it was shown that the conserved SAC protein Mps1 co-purifies with the Smad protein complex and that nocodazole treatment results in Mps1-dependent phosphorylation and consequent activation of Smad2/3 proteins (Zhu et al., 2007). Interestingly, regulation of Smad3 phosphorylation in mitosis was not only dependent on Mps1, but also on ERK activation (Hirschhorn et al., 2012). This raises the possibility of cross-talk between TGF- $\beta$ activation and Ras signaling in mitosis. Another link between TGF- $\beta$ signaling and mitosis involves the transcriptional co-activator protein Ski, which acts as a negative regulator of TGF- $\beta$ signaling. Ski protein levels peak during mitosis and immunofluorescence imaging of U2OS cells demonstrates that Ski localizes at centrosomes and mitotic spindles (Marcelain and Hayman, 2005) and is directly phosphorylated by Aurora A in vitro (Mosquera et al., 2011). The functional significance of this localization became clear through a study demonstrating that Ski-/- MEFs have a weakened SAC and show increased rates of lagging chromosomes during anaphase resulting in micronuclei formation and the generation of aneuploidy and CIN (Marcelain et al., 2012). Thus, the activities of Smads and Ski show that alterations in TGF$\beta$ signaling disrupt chromosome segregation during mitosis to promote CIN.

\section{THE NUCLEAR FACTOR KAPPA-LIGHT-CHAIN ENHANCER OF ACTIVATED B CELLS (NF- $\kappa B$ ) PATHWAY}

The connection between inflammation and cancer was described several decades ago and this connection has been strengthened by the identification of constitutively active NF- $\kappa \mathrm{B}$ signaling in many cancer types (Karin and Greten, 2005; Maeda and Omata, 2008). Induction of this pathway by specific stimuli leads to phosphorylation of the $\mathrm{I} \kappa \mathrm{B}$ complex resulting in its targeted destruction and activation of NF- $\kappa$ B. NF- $\kappa \mathrm{B}$ is then imported in the nucleus where it activates transcription of target genes involved in immune responses and inflammation.

The IкB complex is composed of two catalytic kinase subunits: IKK $\alpha$ and IKK $\beta$ and both kinases have been shown to play distinct roles in mitotic fidelity. Depletion of IKK $\alpha$ in HeLa cells induces a mitotic arrest caused by increased Cyclin B and Plk1. IKK $\alpha$ was also shown to directly phosphorylate and modulate Aurora A kinase activity at centrosomes (Prajapati et al., 2006). These effects appear to be IKK $\beta$-independent, however perturbation of IKK $\beta$ in HeLa cells promotes multipolar spindle formation, chromosome mis-segregation and de-regulation of Aurora A stability. This suggests that disruption of IKK $\alpha$ and IKK $\beta$ converge on Aurora A kinase (Irelan et al., 2007).

Additional involvement of this pathway in mitosis is through signal adapter proteins. The signaling adaptor p62 is necessary for Ras to trigger I $\mathrm{B}$ and consequently activate the NF- $\kappa \mathrm{B}$ pathway. It has also been implicated in mitotic regulation (Moscat and Diaz-Meco, 2012). A recent report demonstrated that Cdk1 phosphorylates p62 to regulate Cyclin B levels during mitosis suggesting that p62 may play a role in SAC maintenance (Linares et al., 2011). Importantly, the authors demonstrate that expression of a nonphosphorylatable p6 2 increases lagging chromosome rates during anaphase and induces micronuclei formation, features which are consistent with the induction of CIN. 


\section{INTEGRIN SIGNALING AND CELL ADHESION}

One important characteristic of transformed cells is their ability to grow in an anchorage-independent fashion and this feature of cancer cells has led to the suggestion that Integrin signaling may play an important role in tumorigenesis. Integrin signaling is thought to couple proliferation and survival signaling with anchoragedependent growth. De-regulated Integrin signaling is thought to provide a metastatic advantage for tumor cells (reviewed in Giancotti and Ruoslahti, 1999).

A key regulator of Integrin signaling is Integrin-linked kinase (ILK). ILK was identified as an interactor of $\beta 1$ - and $\beta 3$-integrin subunits which localizes to both focal adhesions and centrosomes and the cellular functions of ILK include cytoskeleton organization, cell adhesion, and migration (reviewed in Hannigan et al., 2011). ILK levels have been found to be elevated in many cancer types and correlated to poor patient prognosis (McDonald et al., 2008). Recently, ILK was reported to play an important role in centrosome clustering in cancer cell lines by modulating the microtubule associated proteins TACC 3 and ch-TOG (Fielding et al., 2008, 2011). Centrosome de-clustering induces chromosome mis-segregation providing a role for ILKs in mitosis. A more recent study demonstrated that pharmacological inhibition of ILK causes hyper-stabilization of k-MT dynamics resulting in increased centromeric tension in aligned chromosomes (Lim et al., 2013). Stabilization of k-MT attachments is a proven mechanism of CIN in cancer cells (Bakhoum et al., 2009a,b) indicating that ILK is involved in the regulation of proper chromosome segregation and may contribute to CIN.

\section{THE HIPPO SIGNALING PATHWAY}

The Hippo pathway was originally identified in Drosophila and is conserved in mammals. This pathway is responsible for coordinating cell proliferation and apoptosis to govern mechanisms of cell contact inhibition, organ size control, and cancer progression (reviewed in Saucedo and Edgar, 2007). In agreement, this pathway contains both oncogenes and tumor suppressor genes whose homologs have been identified in mammals (Overholtzer et al., 2006; Zender et al., 2006; Harvey and Tapon, 2007).

The first clue that the Hippo signaling pathway could be directly contributing to mitotic progression came from a study reporting that the activity of MST1 and MST2, two essential kinases of the Hippo pathway in mammalian cells, increases during mitosis, and that this effect was enhanced by microtubule-depolymerizing drugs (Praskova et al., 2008). A subsequent study reported that depletion of NDR1, a downstream target of MST kinases, causes MST2-dependent mitotic chromosome misalignment in HeLa cells (Chiba et al., 2009). Independently, NDR phosphorylation by MST1 was also demonstrated to play an important role in the control of centrosome duplication (Hergovich et al., 2009). Similarly to MST2, MST1 was also reported to participate in chromosome alignment by directly phosphorylating Aurora B to limit its kinase activity and promote stable k-MT attachments during mitosis, demonstrating a functional link between Hippo signaling and the correction of k-MT attachment errors (Oh et al., 2010).

Another link between the Hippo pathway and mitosis is through the large tumor suppressor 2 (Lats2). Lats2 is a kinase involved in Hippo signaling which has been shown to inhibit Cdk1 activity in HeLa cells (Kamikubo et al., 2003). Interestingly, Lats2deficient MEFs show severe mitotic defects including centrosome fragmentation, chromosome misalignment, loss of SAC activity, and consequent cytokinesis failure (Yabuta et al., 2007). Furthermore, Lats2 localizes to centrosomes in mitosis and its localization is dependent on phosphorylation by Aurora A (Toji et al., 2004). Finally, the WW domain-containing protein KIBRA (enriched in KIdney and BRAin) was recently identified as a novel regulator of the Hippo pathway and was shown to be phosphorylated by Aurora A, Aurora B (Xiao et al., 2011b), and Lats2 (Xiao et al., 2011a). It was subsequently shown that depletion of KIBRA causes defects in mitotic spindle formation and chromosome alignment suggesting that it is an active player in mitotic fidelity (Zhang et al., 2012). Collectively, these reports show strong evidence that Hippo signaling plays an important role in generating CIN by affecting faithful chromosome segregation during mitosis although many of the molecular mechanisms involving Lats2 and KIBRA in chromosome segregation are currently unclear.

\section{THE DNA DAMAGE RESPONSE}

The DNA damage checkpoint is a conserved molecular mechanism essential for DNA repair and has been commonly associated with the maintenance of genome stability and carcinogenesis (Hoeijmakers, 2001). Intriguingly, this checkpoint responds to DNA damage throughout the cell cycle, except in mitosis. The role of the DNA damage pathway in affecting mitotic fidelity is currently a topic of intense investigation (reviewed in Hayashi and Karlseder, 2013). One area focuses on the role of p53, which in principle contributes to $\mathrm{CIN}$ through two mechanisms. One relates to how the DNA damage pathway responds to chromosome mis-segregation. Loss of p53 function has been shown to provide tolerance for aneuploidy and further propagation of those aneuploid cells can induce CIN (Bunz et al., 2002; Thompson and Compton, 2010). The second relates to how $\mathrm{p} 53$ regulates expression of genes that encode proteins involved in mitosis such as Aurora A, Plk2, and Plk4 (Kurinna et al., 2013). The stabilization of p53 in response to DNA damage increases the expression of these genes hinting at a more direct role in disrupting faithful chromosome segregation.

Numerous studies have implicated DNA damage pathway components other than $\mathrm{p} 53$ in the induction of CIN by tampering with the fidelity of chromosome segregation during mitosis. In mammalian cells, centrosome integrity was shown to be affected upon DNA damage, resulting in multipolarity and consequent chromosome mis-segregation (Hut et al., 2003). Chk1, a component of the DNA damage and replication checkpoints, has been directly implicated in mitotic regulation through several independent mechanisms. First, it is required for centrosome amplification upon DNA damage (Bourke et al., 2007). Second, it participates in the k-MT error correction machinery by directly phosphorylating and enhancing Aurora B activity in vitro (Zachos et al., 2007). Third, Chk1 depletion in human osteosarcoma cells disrupts the SAC by affecting Mad2 and BubR1 levels and consequently increases the rate of chromosome mis-segregation (Carrassa et al., 2009; Peddibhotla et al., 2009). Finally, a recent report has demonstrated that apart from its role in phosphorylating Aurora B, 
Chk1 also directly phosphorylates SAC component Mad2 suggesting multiple levels of mitotic regulation by Chk1 (Chila et al., 2013).

Depletion of Chk2 or abrogation of its kinase activity was shown to cause mitotic delay, promote the generation of lagging chromosomes and consequently induce CIN through a BRCA1-dependent but p53-independent mechanism (Stolz et al., 2010a,b). Importantly, these reports demonstrate that the DNA damage pathway combines tumor-suppressive properties with the maintenance of chromosome integrity (Sato et al., 2010). Chk2, together with Plk1, Cdk1, and 53BP1 (p53-binding protein1) was also postulated to participate in a mitotic phosphorylation feedback network responsible for inactivating the G2/M DNA damage checkpoint (van Vugt et al., 2010). In budding yeast, the Chk2 homolog Rad53, also plays an important role in suppressing the cleavage of sister chromatid cohesion and spindle elongation to preserve genomic stability (Zhang et al., 2009).

In addition, DNA-dependent protein kinase catalytic subunits (DNA-PKcs), known for their active role in DNA nonhomologous end joining (NHEJ), have also been shown to localize to centrosomes, kinetochores, and the midbody (Shang et al., 2010). However, the role that DNA-PKcs play in mitotic fidelity is currently unclear. Importantly, more than $50 \%$ of all cancers carry mutations in components of the DNA damage pathway (Hollstein et al., 1991) and these lines of evidence strongly point to the participation of this pathway in the formation or correction of k-MT attachment errors which are known to be a common cause of CIN.

Despite the compelling evidence that CIN is caused by defective chromosome segregation in mitosis (Cimini et al., 2001; Loncarek et al., 2007; Thompson and Compton, 2008; Bakhoum et al., 2009a; Ganem et al., 2009; Silkworth et al., 2009; Manning et al., 2010; Thompson et al., 2010; Nicholson and Cimini, 2011; Schvartzman et al., 2011; Hood et al., 2012; Kabeche and Compton, 2012; Vitre and Cleveland, 2012), a recent report suggests that CIN is caused by pre-mitotic events induced by replication stress (Burrell et al., 2013). The authors state that most anaphase defects arise through pre-mitotic defects suggesting that activation of DNA damage through replication stress reflects a cause, rather than a consequence, of segregation errors (Burrell et al., 2013). The expected outcome of replication stress is chromosome fragments, including those that are acentric, which was documented in that work. So, that is not surprising. However, the surprise is the proposition that replication stress causes whole chromosome mis-segregation through a mechanism independent of defects of the segregation process in mitosis. DNA replication stress has been observed across several tumor types (Dereli-Oz et al., 2011) and the recent results illustrate a need to search for the mechanism that causes whole chromosome mis-segregation as a consequence of replication stress.

Interestingly, recent work has shown that chromosome segregation defects can lead to DNA damage. For example, it was shown that lagging chromosomes in anaphase tend to be trapped in the cytokinetic furrow resulting in DNA double strand breaks (Hoffelder et al., 2004; Janssen et al., 2011). Also, lagging chromosomes tend to form micronuclei in the subsequent G1 phase.
The chromosomes trapped in micronuclei do not replicate on time with the major nucleus and are occasionally pulverized in the subsequent mitosis (Crasta et al., 2012). These results reveal a potentially vicious cycle. Chromosome segregation errors lead to DNA damage and that damage may promote further chromosome mis-segregation. Analyzing the link between oncogenic signaling and DNA replication might therefore provide important clues regarding the induction of CIN via pre-mitotic events.

\section{SIGNALING PATHWAY CROSS-TALK}

This summary provides convincing evidence for the role of commonly mutated oncogenic signaling pathways in cancer for the induction of CIN. This summary has specifically treated each signaling pathway as an independent linear entity. However, in actuality, there is extensive interconnection between signaling pathways leading to cell-, tissue-, and cancer-type specificity in effects and outcomes of pathway activation. In particular, the specific experimental conditions used to test the role of a signaling pathway could impose a great degree of variability on the results generated and interpretations need to be made carefully based upon the cell, tissue, or cancer model system being employed.

For example, Notch signaling was first linked to tumorigenesis through the identification of a frequent chromosomal translocation found in a subset of human T-cell acute lymphoblastic leukemias (T-ALL) (Ellisen et al., 1991). It has since been shown to be involved in several tumor types (reviewed in Allenspach et al., 2002). Interestingly, Notch can behave as both a dominant oncoprotein and as a tumor suppressor which is not surprising given the diversity of Notch functions reported to date (Lobry et al., 2011). Although Notch mutations have been associated with poor patient prognosis, no clear connections to CIN have thus far been established. However, Notch signaling is connected to most other signaling pathways. Expression of Wnt activates Notch signaling in human mammary epithelial cells and this link has been confirmed in a panel of 34 breast carcinomas suggesting that there is a need for Notch-Wnt cross-talk during mammary tumorigenesis (Ayyanan et al., 2006). TGF- $\beta$ signaling has also been demonstrated to up-regulate Notch in multiple types of mammalian cells and both TGF- $\beta$ and Notch can synergistically regulate the same target genes in many cell types (Blokzijl et al., 2003). Notch ligand JAG2 is induced by Hedgehog signaling during carcinogenesis (Katoh, 2007) and the cross-talk between Ras and Notch pathways has been amply documented in several tumor types including adenocarcinomas, gliomas, leukemias, and breast cancers (Chiang et al., 2008; Kindler et al., 2008; Mittal et al., 2009; Hanlon et al., 2010; Xu et al., 2010). Aberrant Notch signaling can also increase NF- $\kappa \mathrm{B}$ activity by directly interacting with NF- $\mathrm{B}$ and promoting its nuclear retention (Shin et al., 2006). Furthermore, upstream regulators have been shown to combine the promotion of constitutive Notch signaling with an attenuation of the DNA damage pathway (Colaluca et al., 2008) providing evidence to suggest that activation of these pathways via different stimuli may differentially affect how these pathways operate. Thus, Notch signaling may be an important conspirator with these other signaling pathways to affect cell cycle regulation and/or induce CIN. 
Many of these signaling pathways also interconnect with the DNA damage response. For example, the RB pathway has also been shown to cooperate with TGF- $\beta$ signaling in the context of mammary gland development (Francis et al., 2009) and a molecular link between RB signaling, the DNA damage checkpoint and the SAC has recently been reported (Jahn et al., 2013). Crosstalk between the DNA damage pathway and the Hippo pathway via LATS2 has also been established in liver cells (Kurinna et al., 2013). In addition, NF- $\mathrm{B}$ signaling has been shown to cooperate with Ras signaling through the adaptor protein p62 (Linares et al., 2011).

Since cross-talk between pathways is dependent upon intricate feedback loops and intersections at critical nodes that ensure cellular homeostasis it is important to understand the cell-, tissue, and cancer-specific context in how these pathways interact. For example, during breast cancer progression, TGF- $\beta$ represses $\mathrm{NF}-\kappa \mathrm{B}$ in normal cells but activates NF- $\kappa \mathrm{B}$ in malignant counterparts (Neil and Schiemann, 2008). A cautionary note is that many of the results summarized here were obtained using cancer cell lines in which the genetic background is often unknown which may confound clear interpretation. The interconnectedness of cell signaling circuitry adds a layer of complexity that challenges our understanding of how signaling pathways not only drive tumorigenesis but induce CIN.

\section{CONCLUSION}

The oncogenic signaling pathways described here all play dual roles. They act as drivers for tumorigenesis and they induce CIN. This connection to CIN arises because they disrupt the careful orchestration of events required for accurate chromosome segregation during mitosis by decreasing the rate of correction of $\mathrm{k}-\mathrm{MT}$ attachment errors and/or increasing the rate of formation of those errors through extra centrosomes or disruption of centromere geometry. The notion that tumor suppressor genes (and, by extension, oncogenes) combine their known roles in cell cycle progression, growth, and differentiation with the induction of genomic instability is not necessarily new and a substantial body of evidence supports this (reviewed in Coschi and Dick, 2012). The central point we are making here is that the molecular connections between these signaling pathways and CIN are becoming clearer as insights into the underlying mechanisms generating CIN

\section{REFERENCES}

Allenspach, E. J., Maillard, I., Aster, J. C., and Pear, W. S. (2002). Notch signaling in cancer. Cancer Biol. Ther. 1, $466-476$.

Amato, A., Lentini, L., Schillaci, T., Iovino, F., and Di Leonardo, A. (2009a). RNAi mediated acute depletion of retinoblastoma protein (pRb) promotes aneuploidy in human primary cells via micronuclei formation. BMC Cell Biol. 10:79. doi:10.1186/1471-212110-79

Amato, A., Schillaci, T., Lentini, L., and Di Leonardo, A. (2009b). CENPA overexpression promotes genome instability in $\mathrm{pRb}$-depleted human cells. Mol. Cancer 8, 119. doi:10.1186/1476-4598-8-119

Anderhub, S. J., Kramer, A., and Maier, B. (2012). Centrosome amplification in tumorigenesis. Cancer Lett. 322, 8-17. doi:10.1016/j.canlet.2012.02.006

Ayyanan, A., Civenni, G., Ciarloni, L., Morel, C., Mueller, N., Lefort, K., et al. (2006). Increased Wnt signaling triggers oncogenic conversion of human breast epithelial cells by a Notchdependent mechanism. Proc. Natl. Acad. Sci. U.S.A. 103, 3799-3804. doi:10.1073/pnas.0600065103

are married to our understanding of these signaling pathways. Collectively, these reports demonstrate that there is tight communication between mitosis and oncogenic signaling suggesting that mutations leading to mis-regulation of oncogenic pathways not only cause aberrant cell cycle regulation, but also modulate mitosis to generate CIN.

The integration of oncogenic signaling pathways with the induction of CIN changes the way we think about these processes. They can no longer be considered as separate cancer-associated insults. The persistent chromosome mis-segregation in CIN cancer cells provides an agent of genomic change that permits new phenotypes to emerge such as resistance to the toxicity imposed by chemotherapeutic agents. As such, the oncogenic signaling pathways that combine the promotion of cell cycle progression with the induction of CIN may be the most difficult to treat offering some insight into the correlation of CIN and poor patient prognosis. The unanswered question is whether the targeted inhibition of the cancer driving signaling pathway would also rob the cancer cell of its ability to adapt through CIN. Or, once initiated, does CIN become a self-sustaining process that can't be reversed even if the activity from the oncogenic pathway that started it is quelled? Also, why have signaling pathways evolved these dual roles to influence mitotic events? Is their role in mitosis a part of their normal function that becomes exaggerated upon oncogenic activation or is their mitotic role an off-target effect resulting from a dereliction of function after oncogenic activation? Understandably, these dual roles may be of particular value for stable diploid cells where it is important to stall cell cycle progression following chromosome missegregation. However, in the context of tumorigenesis this may turn out to be a double-edged sword that combines de-regulated cell cycle progression with the disruption of mitosis to generate the highly complex karyotypes typical of solid tumors. Our understanding of the links between oncogenic pathways and CIN provide the tools to begin to answer these important questions.

\section{ACKNOWLEDGMENTS}

This work was supported by National Institutes of Health grant GM51542 (Duane A. Compton). We thank Kelly Salmon and Kristina Godek for critical reading of the manuscript.

Bahmanyar, S., Kaplan, D. D., Deluca, J. G., Giddings, T. H. Jr., O’Toole, E. T., Winey, M., et al. (2008). Beta-catenin is a Nek2 substrate involved in centrosome separation. Genes Dev. 22, 91-105. doi:10.1101/gad.1596308

Baker, D. J., Dawlaty, M. M., Wijshake, T., Jeganathan, K. B., Malureanu, L. Van Ree, J. H., et al. (2013). Increased expression of BubR1 protects against aneuploidy and cancer and extends healthy lifespan. Nat. Cell Biol. 15, 96-102. doi:10.1038/ncb2643

Baker, D. J., Jin, F., Jeganathan, K. B., and Van Deursen, J. M. (2009). Whole chromosome instability caused by Bub1 insufficiency drives tumorigenesis through tumor suppressor gene loss of heterozygosity. Cancer Cell 16, 475-486. doi:10.1016/j.ccr.2009.10.023

Bakhoum, S. F., and Compton, D. A. (2009). Cancer: CINful centrosomes. Curr. Biol. 19, R642R645. doi:10.1016/j.cub.2009. 06.039

Bakhoum, S. F., Danilova, O. V., Kaur, P., Levy, N. B., and Compton, D. A. (2011). Chromosomal instability substantiates poor prognosis in patients with diffuse large Bcell lymphoma. Clin. Cancer Res. 17, 7704-7711. doi:10.1158/10780432.CCR-11-2049 
Bakhoum, S. F., Genovese, G., and Compton, D. A. (2009a). Deviant kinetochore microtubule dynamics underlie chromosomal instability. Curr. Biol. 19, 1937-1942. doi:10.1016/j.cub.2009.09.055

Bakhoum, S. F., Thompson, S. L., Manning, A. L., and Compton, D. A. (2009b). Genome stability is ensured by temporal control of kinetochoremicrotubule dynamics. Nat. Cell Biol. 11, 27-35. doi:10.1038/ncb 1809

Barber, T. D., Mcmanus, K., Yuen, K. W., Reis, M., Parmigiani, G., Shen, D., et al. (2008). Chromatid cohesion defects may underlie chromosome instability in human colorectal cancers. Proc. Natl. Acad. Sci. U.S.A. 105, 3443-3448. doi:10.1073/pnas.0712384105

Barcellos-Hoff, M. H., and Akhurst, R. J. (2009). Transforming growth factorbeta in breast cancer: too much, too late. Breast Cancer Res. 11, 202. doi:10.1186/bcr2224

Basto, R., Brunk, K., Vinadogrova, T., Peel, N., Franz, A., Khodjakov, A., et al. (2008). Centrosome amplification can initiate tumorigenesis in flies. Cell 133, 1032-1042. doi:10.1016/j.cell.2008.05.039

Blokzijl, A., Dahlqvist, C., Reissmann, E., Falk, A., Moliner, A., Lendahl, U., et al. (2003). Cross-talk between the Notch and TGF-beta signaling pathways mediated by interaction of the Notch intracellular domain with Smad3. J. Cell Biol. 163, 723-728. doi:10.1083/jcb.200305112

Bobinnec, Y., Morin, X., and Debec, A. (2006). Shaggy/GSK-3beta kinase localizes to the centrosome and to specialized cytoskeletal structures in Drosophila. Cell Motil. Cytoskeleton 63, 313-320. doi:10.1002/cm.20128

Boras-Granic, K., and Wysolmerski, J. J. (2008). Wnt signaling in breast organogenesis. Organogenesis 4, 116-122. doi:10.4161/org.4.2.5858

Bourke, E., Dodson, H., Merdes, A., Cuffe, L., Zachos, G., Walker, M., et al. (2007). DNA damage induces Chk1-dependent centrosome amplification. EMBO Rep. 8, 603-609. doi:10.1038/sj.embor.7400962

Brinkley, B. R. (2001). Managing the centrosome numbers game: from chaos to stability in cancer cell division. Trends Cell Biol. 11, 18-21. doi:10. 1016/S0962-8924(00)01872-9

Bunz, F., Fauth, C., Speicher, M. R., Dutriaux, A., Sedivy, J. M., Kinzler, K. W., et al. (2002). Targeted inactivation of p53 in human cells does not result in aneuploidy. Cancer Res. 62, 1129-1133.
Burkhart, D. L., and Sage, J. (2008). Cellular mechanisms of tumour suppression by the retinoblastoma gene. Nat. Rev. Cancer 8, 671-682. doi:10.1038/nrc2399

Burrell, R. A., Mcclelland, S. E., Endesfelder, D., Groth, P., Weller, M. C., Shaikh, N., et al. (2013). Replication stress links structural and numerical cancer chromosomal instability. Nature 494, 492-496. doi:10.1038/nature11935

Cahill, D. P., Lengauer, C., Yu, J., Riggins, G. J., Willson, J. K., Markowitz, S. D., et al. (1998). Mutations of mitotic checkpoint genes in human cancers. Nature 392, 300-303. doi:10.1038/32688

Cancer Genome Atlas Research Network. (2008). Comprehensive genomic characterization defines human glioblastoma genes and core pathways. Nature 455, 1061-1068. doi:10.1038/nature07385

Cancer Genome Atlas Research Network. (2011). Integrated genomic analyses of ovarian carcinoma. Nature 474, 609-615. doi:10.1038/nature10166

Cancer Genome Atlas Research Network. (2012). Comprehensive genomic characterization of squamous cell lung cancers. Nature 489, 519-525. doi:10.1038/nature11404

Carrassa, L., Sanchez, Y., Erba, E., and Damia, G. (2009). U2OS cells lacking Chk1 undergo aberrant mitosis and fail to activate the spindle checkpoint. J. Cell. Mol. Med. 13, 1565-1576. doi:10.1111/j.15824934.2009.00362.x

Carter, S. L., Eklund, A. C., Kohane, I. S. Harris, L. N., and Szallasi, Z. (2006). A signature of chromosomal instability inferred from gene expression profiles predicts clinical outcome in multiple human cancers. Nat. Genet. 38, 1043-1048. doi:10.1038/ng 1861

Chiang, M. Y., Xu, L., Shestova, O., Histen, G., L'Heureux, S., Romany, C., et al. (2008). Leukemia-associated NOTCH1 alleles are weak tumor initiators but accelerate K-ras-initiated leukemia. J. Clin. Invest. 118, 3181-3194. doi:10.1172/JCI35090

Chiba, S., Ikeda, M., Katsunuma, K., Ohashi, K., and Mizuno, K. (2009). MST2- and Furry-mediated activation of NDR1 kinase is critical for precise alignment of mitotic chromosomes. Curr. Biol. 19, 675-681. doi:10.1016/j.cub.2009.02.054

Chila, R., Celenza, C., Lupi, M., Damia, G., and Carrassa, L. (2013). Chk1-Mad2 interaction: a crosslink between the DNA damage checkpoint and the mitotic spindle checkpoint. Cell Cycle 12, 1083-1090. doi:10.4161/cc.24090

Cimini, D., Howell, B., Maddox, P., Khodjakov, A., Degrassi, F., and Salmon, E. D. (2001). Merotelic kinetochore orientation is a major mechanism of aneuploidy in mitotic mammalian tissue cells. J. Cell Biol. 153, 517-527. doi:10.1083/jcb.153.3.517

Colaluca, I. N., Tosoni, D., Nuciforo, P., Senic-Matuglia, F., Galimberti, V., Viale, G., et al. (2008). NUMB controls p53 tumour suppressor activity. Nature 451, 76-80. doi:10.1038/nature06412

Compton, D. A. (2011). Mechanisms of aneuploidy. Curr. Opin. Cell Biol. 23, 109-113. doi:10.1016/j.ceb.2010.08.007

Coschi, C. H., and Dick, F. A. (2012). Chromosome instability and deregulated proliferation: an unavoidable duo. Cell. Mol. Life Sci. 69, 2009-2024. doi:10.1007/s00018011-0910-4

Coschi, C. H., Martens, A. L., Ritchie, K., Francis, S. M., Chakrabarti, S., Berube, N. G., et al. (2010). Mitotic chromosome condensation mediated by the retinoblastoma protein is tumor-suppressive Genes Dev. 24, 1351-1363. doi:10.1101/gad.1917610

Crasta, K., Ganem, N. J., Dagher, R., Lantermann, A. B., Ivanova, E. V., Pan, Y., et al. (2012). DNA breaks and chromosome pulverization from errors in mitosis. Nature 482, 53-58. doi:10.1038/nature10802

Cui, Y., Borysova, M. K., Johnson, J. O., and Guadagno, T. M. (2010) Oncogenic B-Raf(V600E) induces spindle abnormalities, supernumerary centrosomes, and aneuploidy in human melanocytic cells. Cancer Res. 70, 675-684. doi:10.1158/00085472.CAN-09-1491

Curry, C. L., Reed, L. L., Broude, E., Golde, T. E., Miele, L., and Foreman, K. E. (2007). Notch inhibition in Kaposi's sarcoma tumor cells leads to mitotic catastrophe through nuclear factorkappaB signaling. Mol. Cancer Ther. 6, 1983-1992. doi:10.1158/15357163.MCT-07-0093

Dai, W., Wang, Q., Liu, T., Swamy, M. Fang, Y., Xie, S., et al. (2004). Slippage of mitotic arrest and enhanced tumor development in mice with BubR1 haploin sufficiency. Cancer Res. 64, 440-445. doi:10.1158/00085472.CAN-03-3119

Davalos, V., Suarez-Lopez, L., Castano, J., Messent, A., Abasolo, I., Fernandez, Y., et al. (2012). Human SMC2 protein, a core subunit of human condensin complex, is a novel transcriptional target of the WNT signaling pathway and a new therapeutic target. J. Biol. Chem. 287, 43472-43481. doi:10.1074/jbc.M112.428466

Denko, N. C., Giaccia, A. J., Stringer, J. R., and Stambrook, P. J. (1994). The human Ha-ras oncogene induces genomic instability in murine fibroblasts within one cell cycle. Proc. Natl. Acad. Sci. U.S.A. 91, 5124-5128. doi:10.1073/pnas.91.11.5124

Dereli-Oz, A., Versini, G., and Halazonetis, T. D. (2011). Studies of genomic copy number changes in human cancers reveal signatures of DNA replication stress. Mol Oncol 5, 308-314. doi:10.1016/j.molonc.2011.05.002

Derynck, R., and Zhang, Y. E. (2003). Smad-dependent and Smadindependent pathways in TGF-beta family signalling. Nature 425, 577-584. doi:10.1038/nature02006

Donehower, L. A., Godley, L. A., Aldaz, C. M., Pyle, R., Shi, Y. P., Pinkel, D., et al. (1995). Deficiency of p53 accelerates mammary tumorigenesis in Wnt-1 transgenic mice and promotes chromosomal instability. Genes Dev. 9, 882-895. doi:10.1101/gad.9.7.882

Dong, C., Li, Z., Alvarez, R. Jr., Feng, X. H., and GoldschmidtClermont, P. J. (2000). Microtubule binding to Smads may regulate TGF beta activity. Mol. Cell 5, 27-34. doi:10.1016/S10972765(00)80400-1

Draviam, V. M., Shapiro, I., Aldridge, B., and Sorger, P. K. (2006). Misorientation and reduced stretching of aligned sister kinetochores promote chromosome missegregation in EB1- or APC-depleted cells. ЕMBO J. 25, 2814-2827. doi:10.1038/sj.emboj.7601168

Dumesic, P. A., Scholl, F. A., Barragan, D. I., and Khavari, P. A. (2009). Erk1/2 MAP kinases are required for epidermal G2/M progression. J. Cell Biol. 185, 409-422. doi:10.1083/jcb.200804038

Ellisen, L. W., Bird, J., West, D. C., Soreng, A. L., Reynolds, T. C., Smith, S. D., et al. (1991). TAN-1, the human homolog of the Drosophila notch gene, is broken by chromosomal translocations in $\mathrm{T}$ lymphoblastic neoplasms. Cell 66, 649-661. doi:10.1016/0092-8674(91)90 111-B

Fielding, A. B., Dobreva, I., McDonald, P. C., Foster, L. J., and Dedhar, S. (2008). Integrin-linked kinase 
localizes to the centrosome and regulates mitotic spindle organization. J. Cell Biol. 180, 681-689. doi:10.1083/jcb.200710074

Fielding, A. B., Lim, S., Montgomery, K., Dobreva, I., and Dedhar, S. (2011). A critical role of integrinlinked kinase, ch-TOG and TACC3 in centrosome clustering in cancer cells. Oncogene 30, 521-534. doi:10.1038/onc. 2010.431

Fodde, R., Kuipers, J., Rosenberg, C., Smits, R., Kielman, M., Gaspar, C., et al. (2001). Mutations in the APC tumour suppressor gene cause chromosomal instability. Nat. Cell Biol. 3, 433-438. doi:10.1038/35070129

Francis, S. M., Bergsied, J., Isaac, C. E., Coschi, C. H., Martens, A. L., Hojilla, C. V., et al. (2009). A functional connection between $\mathrm{pRB}$ and transforming growth factor beta in growth inhibition and mammary gland development. Mol. Cell. Biol. 29, 4455-4466. doi:10.1128/MCB.00473-09

Fukasawa, K. (2005). Centrosome amplification, chromosome instability and cancer development. Cancer Lett. 230, 6-19. doi:10.1016/j.canlet.2004.12.028

Ganem, N. J., Godinho, S. A., and Pellman, D. (2009). A mechanism linking extra centrosomes to chromosomal instability. Nature 460, 278-282. doi:10.1038/nature08136

Gascoigne, K. E., and Taylor, S. S. (2008). Cancer cells display profound intraand interline variation following prolonged exposure to antimitotic drugs. Cancer Cell 14, 111-122. doi:10.1016/j.ccr.2008.07.002

Geigl, J. B., Obenauf, A. C., Schwarzbraun, T., and Speicher, M. R. (2008). Defining 'chromosomal instability.' Trends Genet. 24, 64-69. doi:10.1016/j.tig.2007.11.006

Giancotti, F. G., and Ruoslahti, E. (1999). Integrin signaling. Science 285, 1028-1032. doi:10.1126/science.285.5430.1028

Green, R. A., and Kaplan, K. B. (2003). Chromosome instability in colorectal tumor cells is associated with defects in microtubule plus-end attachments caused by a dominant mutation in APC. J. Cell Biol. 163, 949-961. doi:10.1083/jcb.200307070

Green, R. A., Wollman, R., and Kaplan, K. B. (2005). APC and EB1 function together in mitosis to regulate spindle dynamics and chromosome alignment. Mol. Biol. Cell 16, 4609-4622. doi:10.1091/mbc.E0503-0259

Hadjihannas, M. V., and Behrens, J. (2006). CIN By WNT: growth pathways, mitotic control and chromosomal instability in cancer. Cell Cycle 5, 2077-2081. doi:10.4161/cc.5.18.3282

Hadjihannas, M. V., Bruckner, M., and Behrens, J. (2010). Conductin/axin2 and Wnt signalling regulates centrosome cohesion. EMBO Rep. 11, 317-324. doi:10.1038/embor.2010.23

Hadjihannas, M. V., Bruckner, M., Jerchow, B., Birchmeier, W., Dietmaier, W., and Behrens, J. (2006). Aberrant Wnt/beta-catenin signaling can induce chromosomal instability in colon cancer. Proc. Natl. Acad. Sci. U.S.A. 103, 10747-10752. doi:10.1073/pnas.0604206103

Hanahan, D., and Weinberg, R. A. (2000). The hallmarks of cancer. Cell 100, 57-70. doi:10.1016/S00928674(00)81683-9

Hanahan, D., and Weinberg, R. A. (2011). Hallmarks of cancer: the next generation. Cell 144, 646-674. doi:10.1016/j.cell.2011.02.013

Hanks, S., Coleman, K., Reid, S., Plaja, A., Firth, H., Fitzpatrick, D., et al. (2004). Constitutional aneuploidy and cancer predisposition caused by biallelic mutations in BUB1B. Nat. Genet. 36, 1159-1161. doi:10.1038/ng1449

Hanlon, L., Avila, J. L., Demarest, R. M., Troutman, S., Allen, M., Ratti, F., et al. (2010). Notch1 functions as a tumor suppressor in a model of K-ras-induced pancreatic ductal adenocarcinoma. Cancer Res. 70, 4280-4286. doi:10.1158/00085472.CAN-09-4645

Hannigan, G. E., McDonald, P. C., Walsh, M. P., and Dedhar, S. (2011). Integrin-linked kinase: not so 'pseudo' after all. Oncogene 30, 4375-4385. doi:10.1038/onc.2011.177

Harvey, K., and Tapon, N. (2007). The Salvador-Warts-Hippo pathway-an emerging tumour-suppressor network. Nat. Rev. Cancer 7, 182-191. doi:10.1038/nrc2070

Hayashi, M. T., and Karlseder, J. (2013). DNA damage associated with mitosis and cytokinesis failure. Oncogene doi:10.1038/onc.2012.615

Hergovich, A., Kohler, R. S., Schmitz, D., Vichalkovski, A., Cornils, H., and Hemmings, B. A. (2009). The MST1 and hMOB1 tumor suppressors control human centrosome duplication by regulating NDR kinase phosphorylation. Curr. Biol. 19, 1692-1702. doi:10.1016/j.cub.2009.09.020

Hernando, E., Nahle, Z., Juan, G., Diaz-Rodriguez, E., Alaminos, M., Hemann, M., et al. (2004). Rb inactivation promotes genomic instability by uncoupling cell cycle progression from mitotic control. Nature 430 797-802. doi:10.1038/nature02820

Hirschhorn, T., Barizilay, L., Smorodinsky, N. I., and Ehrlich, M. (2012). Differential regulation of $\operatorname{Smad} 3$ and of the type II transforming growth factor-beta receptor in mitosis: implications for signaling. PLoS ONE 7:e43459. doi:10.1371/journal.pone.0043459

Hoeijmakers, J. H. (2001). Genome maintenance mechanisms for preventing cancer. Nature 411, 366-374 doi:10.1038/35077232

Hoffelder, D. R., Luo, L., Burke, N. A., Watkins, S. C., Gollin, S. M., and Saunders, W. S. (2004). Resolution of anaphase bridges in cancer cells. Chromosoma 112, 389-397. doi:10.1007/s00412-004-0284-6

Hollstein, M., Sidransky, D., Vogelstein, B., and Harris, C. C. (1991). p53 mutations in human cancers. Science 253, 49-53. doi:10.1126/science.1905840

Hood, E. A., Kettenbach, A. N., Gerber, S. A., and Compton, D. A. (2012). Plk1 regulates the kinesin-13 protein Kif2b to promote faithful chromosome segregation. Mol. Biol. Cell 23, 2264-2274. doi:10.1091/mbc.E1112-1013

Hut, H. M., Lemstra, W., Blaauw, E. H., Van Cappellen, G. W., Kampinga, H. H., and Sibon, O. C. (2003). Centrosomes split in the presence of impaired DNA integrity during mitosis. Mol. Biol. Cell 14, 1993-2004. doi:10.1091/mbc.E0208-0510

Ichikawa, T., Kyprianou, N., and Isaacs, J. T. (1990). Genetic instability and the acquisition of metastatic ability by rat mammary cancer cells following v-H-ras oncogene transfection. Cancer Res. 50, 6349-6357.

Indjeian, V. B., and Murray, A. W. (2007). Budding yeast mitotic chromosomes have an intrinsic bias to biorient on the spindle. Curr. Biol. 17, 1837-1846. doi:10.1016/j.cub.2007.09.056

Irelan, J. T., Murphy, T. J., Dejesus, P. D., Teo, H., Xu, D., GomezFerreria, M. A., et al. (2007). A role for IkappaB kinase 2 in bipolar spindle assembly. Proc. Natl. Acad. Sci. U.S.A. 104, 16940-16945. doi:10.1073/pnas.0706493104

Isaac, C. E., Francis, S. M., Martens, A. L., Julian, L. M., Seifried, L. A., Erdmann, N., et al. (2006). The retinoblastoma protein regulates pericentric heterochromatin. Mol. Cell. Biol. 26, 3659-3671. doi:10.1128/MCB.26.9.36593671.2006
Jahn, S., Corsino, P., Davis, B., Law, M., Norgaard, P., and Law, B. (2013). Constitutive Cdk2 activity promotes aneuploidy while altering the spindle assembly and tetraploidy checkpoints. J. Cell. Sci. 126, 1207-1217. doi:10.1242/jcs.117382

Janssen, A., Van Der Burg, M., Szuhai, K., Kops, G. J., and Medema, R. H. (2011). Chromosome segregation errors as a cause of DNA damage and structural chromosome aberrations. Science 333, 1895-1898. doi:10.1126/science. 1210214

Jones, S., Zhang, X., Parsons, D. W. Lin, J. C., Leary, R. J., Angenendt, P., et al. (2008). Core signaling pathways in human pancreatic cancers revealed by global genomic analyses. Science 321, 1801-1806. doi:10.1126/science.1164368

Kabeche, L., and Compton, D. A. (2012) Checkpoint-independent stabilization of kinetochore-microtubule attachments by Mad2 in human cells. Curr. Biol. 22, 638-644. doi:10.1016/j.cub.2012.02.030

Kamata, T., and Pritchard, C. (2011). Mechanisms of aneuploidy induction by RAS and RAF oncogenes. Am. J. Cancer Res. 1, 955-971.

Kamikubo, Y., Takaori-Kondo, A., Uchiyama, T., and Hori, T. (2003). Inhibition of cell growth by conditional expression of $\mathrm{kpm}$, a human homologue of Drosophila warts/lats tumor suppressor. J. Biol. Chem. 278, 17609-17614. doi:10.1074/jbc.M211974200

Kaplan, D. D., Meigs, T. E., Kelly, P., and Casey, P. J. (2004). Identification of a role for beta-catenin in the establishment of a bipolar mitotic spindle. J. Biol. Chem. 279, 10829-10832. doi:10.1074/jbc.C400035200

Karin, M., and Greten, F. R. (2005). NFkappaB: linking inflammation and immunity to cancer development and progression. Nat. Rev. Immunol. 5, 749-759. doi:10.1038/nri1703

Katoh, M. (2007). Networking of WNT, FGF, Notch, BMP, and Hedgehog signaling pathways during carcinogenesis. Stem Cell. Rev. 3, 30-38. doi:10.1007/s12015-007-0006-6

Kikuchi, K., Niikura, Y., Kitagawa, K., and Kikuchi, A. (2010). Dishevelled, a Wnt signalling component, is involved in mitotic progression in cooperation with Plk1. EMBO J. 29, 3470-3483. doi:10.1038/emboj.2010.221

Kindler, T., Cornejo, M. G., Scholl, C., Liu, J., Leeman, D. S., Haydu, J. E., et al. (2008). K-RasG12Dinduced T-cell lymphoblastic lymphoma/leukemias harbor Notch1 mutations and are sensitive to 
gamma-secretase inhibitors. Blood 112, 3373-3382. doi:10.1182/blood2008-03-147587

Knauf, J. A., Ouyang, B., Knudsen, E. S., Fukasawa, K., Babcock, G., and Fagin, J. A. (2006). Oncogenic RAS induces accelerated transition through G2/M and promotes defects in the G2 DNA damage and mitotic spindle checkpoints. J. Biol. Chem. 281, 3800-3809. doi:10.1074/jbc.M511690200

Kops, G. J., Foltz, D. R., and Cleveland, D. W. (2004). Lethality to human cancer cells through massive chromosome loss by inhibition of the mitotic checkpoint. Proc. Natl. Acad. Sci. U.S.A. 101, 8699-8704. doi:10.1073/pnas.0401142101

Kops, G. J., Weaver, B. A., and Cleveland, D. W. (2005). On the road to cancer: aneuploidy and the mitotic checkpoint. Nat. Rev. Cancer 5, 773-785. doi:10.1038/nrc1714

Kurinna, S., Stratton, S. A., Coban, Z., Schumacher, J. M., Grompe, M., Duncan, A. W., et al. (2013). p53 regulates a mitotic transcription program and determines ploidy in normal mouse liver. Hepatology 57, 2004-2013. doi:10.1002/hep.26233

Kuukasjarvi, T., Karhu, R., Tanner, M., Kahkonen, M., Schaffer, A., Nupponen, N., et al. (1997). Genetic heterogeneity and clonal evolution underlying development of asynchronous metastasis in human breast cancer. Cancer Res. 57, 1597-1604.

Lampson, M. A., Renduchitala, K., Khodjakov, A., and Kapoor, T. M. (2004). Correcting improper chromosome-spindle attachments during cell division. Nat. Cell Biol. 6, 232-237. doi:10.1038/ncb1102

Lee, A. J., Endesfelder, D., Rowan, A. J., Walther, A., Birkbak, N. J., Futreal, P. A., et al. (2011). Chromosomal instability confers intrinsic multidrug resistance. Cancer Res. 71, 1858-1870. doi:10.1158/00085472.CAN-10-3604

Lengauer, C., Kinzler, K. W., and Vogelstein, B. (1997). Genetic instability in colorectal cancers. Nature 386, 623-627. doi:10.1038/386623a0

Lim, S., Kawamura, E., Fielding, A. B., Maydan, M., and Dedhar, S. (2013). Integrin-linked kinase regulates interphase and mitotic microtubule dynamics. PLOS ONE 8:e53702. doi:10.1371/journal.pone.0053702

Linares, J. F., Amanchy, R., Greis, K., Diaz-Meco, M. T., and Moscat, J. (2011). Phosphorylation of p62 by cdkl controls the timely transit of cells through mitosis and tumor cell proliferation. Mol. Cell. Biol. 31,
105-117. doi:10.1128/MCB.0062010

Lobry, C., Oh, P., and Aifantis, I. (2011). Oncogenic and tumor suppressor functions of Notch in cancer: it's NOTCH what you think. J. Exp. Med. 208, 1931-1935. doi:10.1084/jem.20111855

Loncarek, J., Kisurina-Evgenieva, O., Vinogradova, T., Hergert, P., La Terra, S., Kapoor, T. M., et al. (2007). The centromere geometry essential for keeping mitosis error free is controlled by spindle forces. Nature 450, 745-749. doi:10.1038/nature06344

Lou, Y., Xie, W., Zhang, D. F., Yao, J. H., Luo, Z. F., Wang, Y. Z., et al. (2004). Nek2A specifies the centrosomal localization of Erk2. Biochem. Biophys. Res. Commun. 321, 495-501. doi:10.1016/j.bbrc.2004.06.171

Luo, J., Emanuele, M. J., Li, D., Creighton, C. J., Schlabach, M. R., Westbrook, T. F., et al. (2009). A genome-wide RNAi screen identifies multiple synthetic lethal interactions with the Ras oncogene. Cell 137, 835-848. doi:10.1016/j.cell.2009.05.006

Maeda, S., and Omata, M. (2008). Inflammation and cancer: role of nuclear factor-kappaB activation. Cancer Sci. 99, 836-842. doi:10.1111/j.13497006.2008.00763.x

Malumbres, M., and Barbacid, M. (2003). RAS oncogenes: the first 30 years. Nat. Rev. Cancer 3, 459-465. doi:10.1038/nrc1193

Manning, A. L., Longworth, M. S., and Dyson, N. J. (2010). Loss of $\mathrm{pRB}$ causes centromere dysfunction and chromosomal instability. Genes Dev. 24, 1364-1376. doi:10.1101/gad.1917310

Marcelain, K., Armisen, R., Aguirre, A., Ueki, N., Toro, J., Colmenares, C., et al. (2012). Chromosomal instability in mouse embryonic fibroblasts null for the transcriptional co-repressor Ski. J. Cell. Physiol. 227, 278-287. doi:10.1002/jcp.22733

Marcelain, K., and Hayman, M. J. (2005). The Ski oncoprotein is upregulated and localized at the centrosomes and mitotic spindle during mitosis. Oncogene 24, 4321-4329. doi:10.1038/sj.onc. 1208631

Marshall, C. J. (1991). Tumor suppressor genes. Cell 64, 313-326. doi:10.1016/0092-8674(91)90641-B

Massague, J. (2008). TGFbeta in cancer. Cell 134, 215-230. doi:10.1016/j.cell.2008.07.001

Mayhew, C. N., Carter, S. L., Fox, S. R., Sexton, C. R., Reed, C. A., Srinivasan, S. V., et al. (2007). RB loss abrogates cell cycle control and genome integrity to promote liver tumorigenesis. Gastroenterology 133, 976-984. doi:10.1053/j.gastro.2007.06.025

McDonald, P. C., Fielding, A. B., and Dedhar, S. (2008). Integrin-linked kinase - essential roles in physiology and cancer biology. J. Cell. Sci. 121, 3121-3132. doi:10.1242/jcs.017996

McGranahan, N., Burrell, R. A., Endesfelder, D., Novelli, M. R., and Swanton, C. (2012). Cancer chromosomal instability: therapeutic and diagnostic challenges. $E M B O$ Rep. 13, 528-538. doi:10.1038/embor.2012.61

Michel, L. S., Liberal, V., Chatterjee, A., Kirchwegger, R., Pasche, B., Gerald, W., et al. (2001). MAD2 haploinsufficiency causes premature anaphase and chromosome instability in mammalian cells. Nature 409, 355-359. doi:10.1038/35053094

Mittal, S., Subramanyam, D., Dey, D., Kumar, R. V., and Rangarajan, A. (2009). Cooperation of Notch and Ras/MAPK signaling pathways in human breast carcinogenesis. Mol Cancer 8, 128. doi:10.1186/14764598-8-128

Moscat, J., and Diaz-Meco, M. T. (2012). p62: a versatile multitasker takes on cancer. Trends Biochem. Sci. 37, 230-236. doi:10.1016/j.tibs.2012.02.008

Mosquera, J., Armisen, R., Zhao, H., Rojas, D. A., Maldonado, E. Tapia, J. C., et al. (2011). Identification of Ski as a target for Aurora A kinase. Biochem. Biophys. Res. Commun. 409, 539-543. doi:10.1016/j.bbrc.2011.05.040

Neil, J. R., and Schiemann, W. P. (2008). Altered TAB1:I kappaB kinase interaction promotes transforming growth factor beta-mediated nuclear factor-kappaB activation during breast cancer progression. Cancer Res. 68, 1462-1470. doi:10.1158/0008-5472.CAN-073094

Ng, T. M., Waples, W. G., Lavoie, B. D., and Biggins, S. (2009). Pericentromeric sister chromatid cohesion promotes kinetochore biorientation. Mol. Biol. Cell 20, 3818-3827. doi:10.1091/mbc.E09-04-0330

Nicholson, J. M., and Cimini, D. (2011). How mitotic errors contribute to karyotypic diversity in cancer. $A d v$. Cancer Res. 112, 43-75. doi:10. 1016/B978-0-12-387688-1.00003-X

Niehrs, C., and Acebron, S. P. (2012). Mitotic and mitogenic Wnt signalling. EMBO J. 31, 2705-2713. doi:10.1038/emboj.2012.124

Nigg, E. A. (2002). Centrosome aberrations: cause or consequence of cancer progression? Nat. Rev. Cancer 2, 815-825. doi:10.1038/nrc924

Oh, H. J., Kim, M. J., Song, S. J., Kim, T., Lee, D., Kwon, S. H., et al. (2010). MST1 limits the kinase activity of aurora B to promote stable kinetochore-microtubule attachment. Curr. Biol. 20, 416-422. doi:10.1016/j.cub.2009.12.054

Overholtzer, M., Zhang, J., Smolen, G. A., Muir, B., Li, W., Sgroi, D. C., et al. (2006). Transforming properties of YAP, a candidate oncogene on the chromosome 11q22 amplicon. Proc. Natl. Acad. Sci. U.S.A. 103, 12405-12410. doi:10.1073/pnas.0605579103

Padua, D., and Massague, J. (2009). Roles of TGFbeta in metastasis. Cell Res. 19, 89-102. doi:10.1038/cr.2008.316

Peddibhotla, S., Lam, M. H., GonzalezRimbau, M., and Rosen, J. M. (2009). The DNA-damage effector checkpoint kinase 1 is essential for chromosome segregation and cytokinesis. Proc. Natl. Acad. Sci. U.S.A. 106, 5159-5164. doi:10.1073/pnas.0806671106

Pinsky, B. A., Kung, C., Shokat, K. M., and Biggins, S. (2006). The Ipl1Aurora protein kinase activates the spindle checkpoint by creating unattached kinetochores. Nat. Cell Biol. 8, 78-83. doi:10.1038/ncb1341

Prajapati, S., Tu, Z., Yamamoto, Y., and Gaynor, R. B. (2006). IKKalpha regulates the mitotic phase of the cell cycle by modulating Aurora A phosphorylation. Cell Cycle 5, 2371-2380. doi:10.4161/cc.5.20.3359

Praskova, M., Xia, F., and Avruch, J. (2008). MOBKL1A/MOBKL1B phosphorylation by MST1 and MST2 inhibits cell proliferation. Curr. Biol. 18, 311-321. doi:10.1016/j.cub.2008.02.006

Prosperi, J. R., and Goss, K. H. (2010). A Wnt-ow of opportunity: targeting the Wnt/beta-catenin pathway in breast cancer. Curr. Drug Targets 11, 1074-1088. doi:10.2174/13894501079200 6780

Quintyne, N. J., Reing, J. E., Hoffelder, D. R., Gollin, S. M., and Saunders, W. S. (2005). Spindle multipolarity is prevented by centrosomal clustering. Science 307, 127-129. doi:10.1126/science.1104905

Ren, B., Cam, H., Takahashi, Y., Volkert, T., Terragni, J., Young, R. A., et al. (2002). E2F integrates cell cycle progression with DNA repair, replication, and $\mathrm{G}(2) / \mathrm{M}$ checkpoints. Genes Dev. 16, 245-256. doi:10.1101/gad.949802 
Ruan, K., Ye, F., Li, C., Liou, Y. C., Lin, S. C., and Lin, S. Y. (2012). PLK1 interacts and phosphorylates Axin that is essential for proper centrosome formation. PLoS ONE 7:e49184. doi:10.1371/journal.pone.0049184

Saavedra, H. I., Knauf, J. A., Shirokawa, J. M., Wang, J., Ouyang, B., Elisei, R., et al. (2000). The RAS oncogene induces genomic instability in thyroid PCCL3 cells via the MAPK pathway. Oncogene 19, 3948-3954. doi:10.1038/sj.onc.1203723

Sage, J., and Straight, A. F. (2010). RB's original CIN? Genes Dev. 24, 1329-1333. doi:10.1101/gad.1948010

Sakuno, T., Tada, K., and Watanabe, Y. (2009). Kinetochore geometry defined by cohesion within the centromere. Nature 458, 852-858. doi:10.1038/nature07876

Sato, K., Ohta, T., and Venkitaraman, A. R. (2010). A mitotic role for the DNA damage-responsive CHK2 kinase. Nat. Cell Biol. 12, 424-425. doi:10.1038/ncb0510-424

Saucedo, L. J., and Edgar, B. A. (2007). Filling out the Hippo pathway. Nat. Rev. Mol. Cell Biol. 8, 613-621. doi:10.1038/nrm2221

Schvartzman, J. M., Duijf, P. H., Sotillo, R., Coker, C., and Benezra, R. (2011). Mad2 is a critical mediator of the chromosome instability observed upon $\mathrm{Rb}$ and $\mathrm{p} 53$ pathway inhibition. Cancer Cell 19, 701-714. doi:10.1016/j.ccr.2011.04.017

Schvartzman, J. M., Sotillo, R., and Benezra, R. (2010). Mitotic chromosomal instability and cancer: mouse modelling of the human disease. Nat. Rev. Cancer 10, 102-115. doi:10.1038/nrc2781

Shang, Z. F., Huang, B., Xu, Q. Z., Zhang, S. M., Fan, R., Liu, X. D., et al. (2010). Inactivation of DNAdependent protein kinase leads to spindle disruption and mitotic catastrophe with attenuated checkpoint protein 2 Phosphorylation in response to DNA damage. Cancer Res. 70, 3657-3666. doi:10. 1158/0008-5472.CAN-09-3362

Shapiro, P. S., Vaisberg, E., Hunt, A. J., Tolwinski, N. S., Whalen, A. M., Mcintosh, J. R., et al. (1998). Activation of the MKK/ERK pathway during somatic cell mitosis: direct interactions of active ERK with kinetochores and regulation of the mitotic 3F3/2 phosphoantigen. J. Cell Biol. 142, 1533-1545. doi:10.1083/jcb.142.6.1533

Shin, H. M., Minter, L. M., Cho, O. H., Gottipati, S., Fauq, A. H., Golde, T. E., et al. (2006). Notch1 augments NF-kappaB activity by facilitating its nuclear retention. EMBO J. 25, 129-138. doi:10.1038/sj.emboj.7600902

Silkworth, W. T., Nardi, I. K., Scholl, L. M., and Cimini, D. (2009). Multipolar spindle pole coalescence is a major source of kinetochore mis-attachment and chromosome mis-segregation in cancer cells. PLoS ONE 4:e6564. doi:10.1371/journal.pone.0006564

Smid, M., Hoes, M., Sieuwerts, A. M., Sleijfer, S., Zhang, Y., Wang, Y., et al. (2011). Patterns and incidence of chromosomal instability and their prognostic relevance in breast cancer subtypes. Breast Cancer Res. Treat. 128, 23-30. doi:10.1007/s10549-010-1026-5

Sotillo, R., Schvartzman, J. M., Socci, N. D., and Benezra, R. (2010). Mad2-induced chromosome instability leads to lung tumour relapse after oncogene withdrawal. Nature 464, 436-440. doi:10.1038/nature0 8803

Srinivasan, S. V., Mayhew, C. N., Schwemberger, S., Zagorski, W., and Knudsen, E. S. (2007). RB loss promotes aberrant ploidy by deregulating levels and activity of DNA replication factors. J. Biol. Chem. 282, 23867-23877. doi:10.1074/jbc.M700542200

Stolz, A., Ertych, N., and Bastians, H. (2010a). Loss of the tumoursuppressor genes CHK2 and BRCA1 results in chromosomal instability. Biochem. Soc. Trans. 38, 1704-1708. doi:10.1042/BST0381704

Stolz, A., Ertych, N., Kienitz, A., Vogel, C., Schneider, V., Fritz, B., et al. (2010b). The CHK2-BRCA1 tumour suppressor pathway ensures chromosomal stability in human somatic cells. Nat. Cell Biol. 12, 492-499. doi:10.1038/ncb2051

Storchova, Z., and Pellman, D. (2004). From polyploidy to aneuploidy, genome instability and cancer. Nat. Rev. Mol. Cell Biol. 5, 45-54. doi:10.1038/nrm1276

Suijkerbuijk, S. J., Van Osch, M. H., Bos, F. L., Hanks, S., Rahman, N., and Kops, G. J. (2010). Molecular causes for BUBR1 dysfunction in the human cancer predisposition syndrome mosaic variegated aneuploidy. Cancer Res. 70, 4891-4900. doi:10.1158/00085472.CAN-09-4319

Swanton, C., Nicke, B., Schuett, M., Eklund, A. C., Ng, C., Li, Q., et al. (2009). Chromosomal instability determines taxane response. Proc. Natl. Acad. Sci. U.S.A. 106, 8671-8676. doi:10.1073/pnas.0811835106
Thompson, S. L., Bakhoum, S. F., and Compton, D. A. (2010). Mechanisms of chromosomal instability. Curr. Biol. 20, R285-295. doi:10.1016/j.cub.2010.01.034

Thompson, S. L., and Compton, D. A. (2008). Examining the link between chromosomal instability and aneuploidy in human cells. J. Cell Biol. 180, 665-672. doi:10.1083/jcb.200712029

Thompson, S. L., and Compton, D. A. (2010). Proliferation of aneuploid human cells is limited by a p53-dependent mechanism. J. Cell Biol. 188, 369-381. doi:10.1083/jcb.200905057

Tighe, A., Johnson, V. L., Albertella, M., and Taylor, S. S. (2001). Aneuploid colon cancer cells have a robust spindle checkpoint. $E M B O$ Rep. 2, 609-614. doi:10.1093/emboreports/kve127

Tighe, A., Ray-Sinha, A., Staples, O. D., and Taylor, S. S. (2007). GSK3 inhibitors induce chromosome instability. BMC Cell Biol. 8:34. doi:10.1186/1471-2121-8-34

Toji, S., Yabuta, N., Hosomi, T., Nishihara, S., Kobayashi, T., Suzuki, S., et al. (2004). The centrosomal protein Lats2 is a phosphorylation target of Aurora-A kinase. Genes Cells 9, 383-397. doi:10.1111/j.13569597.2004.00732.x

van Harn, T., Foijer, F., Van Vugt, M. Banerjee, R., Yang, F., Oostra, A., et al. (2010). Loss of Rb proteins causes genomic instability in the absence of mitogenic signaling. Genes Dev. 24, 1377-1388. doi:10.1101/gad.58 0710

van Vugt, M. A., Gardino, A. K., Linding, R., Ostheimer, G. J., Reinhardt, H. C., Ong, S. E., et al. (2010). A mitotic phosphorylation feedback network connects Cdk1, Plk1, 53BP1, and Chk2 to inactivate the $\mathrm{G}(2) / \mathrm{M}$ DNA damage checkpoint. PLoS Biol. 8:e1000287. doi:10.1371/journal.pbio.1000287

Vitre, B. D., and Cleveland, D. W. (2012). Centrosomes, chromosome instability (CIN) and aneuploidy. Curr. Opin. Cell Biol. 24, 809-815. doi:10.1016/j.ceb.2012.10.006

Wakefield, J. G., Stephens, D. J., and Tavare, J. M. (2003). A role for glycogen synthase kinase-3 in mitotic spindle dynamics and chromosome alignment. J. Cell. Sci. 116, 637-646. doi:10.1242/jcs.00273

Walther, A., Houlston, R., and Tomlinson, I. (2008). Association between chromosomal instability and prognosis in colorectal cancer: a meta-analysis. Gut 57, 941-950. doi:10.1136/gut.2007.135004
Weaver, B. A., Silk, A. D., Montagna, C., Verdier-Pinard, P., and Cleveland, D. W. (2007). Aneuploidy acts both oncogenically and as a tumor suppressor. Cancer Cell 11, 25-36. doi:10.1016/j.ccr.2006.12.003

Woo, R. A., and Poon, R. Y. (2004). Activated oncogenes promote and cooperate with chromosomal instability for neoplastic transformation. Genes Dev. 18, 1317-1330. doi:10.1101/gad.1165204

Xiao, L., Chen, Y., Ji, M., and Dong, J. (2011a). KIBRA regulates Hippo signaling activity via interactions with large tumor suppressor kinases. J. Biol. Chem. 286, 7788-7796. doi:10.1074/jbc.M110.173468

Xiao, L., Chen, Y., Ji, M., Volle, D. J., Lewis, R. E., Tsai, M. Y., et al. (2011b). KIBRA protein phosphorylation is regulated by mitotic kinase aurora and protein phosphatase 1 . J. Biol. Chem. 286, 36304-36315. doi:10.1074/jbc.M111.246850

Xu, P., Qiu, M., Zhang, Z., Kang, C., Jiang, R., Jia, Z., et al. (2010). The oncogenic roles of Notch1 in astrocytic gliomas in vitro and in vivo. J. Neurooncol. 97, 41-51. doi:10.1007/s11060-009-0007-1

Yabuta, N., Okada, N., Ito, A., Hosomi, T., Nishihara, S., Sasayama, Y., et al. (2007). Lats2 is an essential mitotic regulator required for the coordination of cell division. J. Biol. Chem. 282, 19259-19271. doi:10.1074/jbc.M608562200

Yang, Z., Loncarek, J., Khodjakov, A., and Rieder, C. L. (2008) Extra centrosomes and/or chromosomes prolong mitosis in human cells. Nat. Cell Biol. 10, 748-751. doi:10.1038/ncb1738

Zachos, G., Black, E. J., Walker, M., Scott, M. T., Vagnarelli, P., Earnshaw, W. C., et al. (2007). Chk1 is required for spindle checkpoint function. Dev. Cell 12, 247-260. doi:10.1016/j.devcel.2007.01.003

Zender, L., Spector, M. S., Xue, W., Flemming, P., Cordon-Cardo, C., Silke, J., et al. (2006). Identification and validation of oncogenes in liver cancer using an integrative oncogenomic approach. Cell 125, 1253-1267. doi:10.1016/j.cell.2006.05.030

Zhang, L., Iyer, J., Chowdhury, A., Ji, M., Xiao, L., Yang, S., et al. (2012). KIBRA regulates aurora kinase activity and is required for precise chromosome alignment during mitosis. J. Biol. Chem. 287, 34069-34077. doi:10.1074/jbc.M112.385518

Zhang, T., Nirantar, S., Lim, H. H., Sinha, I., and Surana, U. (2009). DNA damage checkpoint maintains $\mathrm{CDH} 1$ in an active 
state to inhibit anaphase progression. Dev. Cell 17, 541-551. doi:10.1016/j.devcel.2009.09.006

Zhu, S., Wang, W., Clarke, D. C., and Liu, X. (2007). Activation of Mps1 promotes transforming growth factorbeta-independent Smad signaling. J. Biol. Chem. 282, 18327-18338. doi:10.1074/jbc.M700636200

Zumbrunn, J., Kinoshita, K., Hyman, A. A., and Nathke, I. S. (2001). Binding of the adenomatous polyposis coli protein to microtubules increases microtubule stability and is regulated by GSK3 beta phosphorylation. Curr. Biol. 11, 44-49. doi:10.1016/S0960-9822(01)00 002-1

Conflict of Interest Statement: The authors declare that the research was conducted in the absence of any commercial or financial relationships that could be construed as a potential conflict of interest.

Received: 30 April 2013; accepted: 06 June 2013; published online: 27 June 2013. Citation: Orr B and Compton DA (2013) A double-edged sword: how oncogenes and tumor suppressor genes can contribute to chromosomal instability. Front. Oncol. 3:164. doi: 10.3389/fonc.2013.00164
This article was submitted to Frontiers in Molecular and Cellular Oncology, a specialty of Frontiers in Oncology.

Copyright (c) 2013 Orr and Compton.

This is an open-access article distributed under the terms of the Creative Commons Attribution License, which permits use, distribution and reproduction in other forums, provided the original authors and source are credited and subject to any copyright notices concerning any third-party graphics etc. 